\title{
Echoes of LAEMOS
}

This issue is based on a selection of papers presented at the $3^{\text {rd }}$ Latin American and European Meeting on Organization Studies (LAEMOS), which was held in Buenos Aires, Argentina on 7-10 April 2010. The conference aims to promote the diffusion of research conducted primarily in Latin America and Europe and it is based on contributions of high quality academic work within the field of organization studies and related areas. It encourages interdisciplinary studies that link micro level case analysis to macro level institutional and global forces, that investigate processes as well as structures, and that take a historical and contextual approach. Since the first edition in Puebla (2006) and after the successful meetings in Rio de Janeiro (2008) and Buenos Aires (2010), LAEMOS has established itself as the premier conference on Organization Studies in Latin America.

The general theme of LAEMOS 2010 was Constructing and Disrupting Social Realities: Tales of Development and Crisis in Markets, Institutions and Organizations. Markets, institutions and organizations are important factors in sustaining economic exchange, providing political stability and fostering material production and innovation. At the same time, they are the means by which social identities are anchored and collective meanings are constituted and reproduced. In doing so they play a critical role in the construction of social realities.

In today's unstable and risky world, Latin American and European markets, institutions and organizations have increasingly come under pressure, although in different forms and to varying degrees. Because of that, their instrumental and symbolic roles are called into question; their sensegiving function is jeopardized; and they have a hard time in fulfilling their purposes. In times of crisis, markets may turn from being levers for development into causes or conditions for economic and political decline, and an endogenous source of social disruption. But as markets become more vulnerable to crisis and disruption, institutions become more salient as the basic infrastructure for stability and development. Under these circumstances, contemporary organizations face the challenge of making sense of emerging configurations of markets-institutions. Caught in the interplay of market and institutional forces, they need to maintain legitimacy, adapt to new competitive rules, and rethink their role as economic and social agents.

The papers contained in this issue enhance empirical and theoretical studies on the dynamics of development and crisis with specific reference to Latin American and European societies. Under the general theme of the meeting, they connect and mix a broad variety of studies, narratives and discourses on the present times of crisis and on future perspectives of development and innovation.

The paper by Salgado reflects on the notion of Sumaq Kawsay - a Quechua expression commonly translated as "well-living" in opposition to "well-being" - recently introduced in the Ecuadorian and Bolivian constitutions. Drawing on the work of Brazilian scholars Alberto Guerreiro-Ramos and Fernando Tenório, the author critically explores the extent to which Sumaq Kawsay can promote new forms of economic development based on cooperation and empowered social participation (deliberative citizenship). 
The work of Brazilian sociologist Alberto Guerreiro Ramos also informs the paper by Dornelas Camara et al. The authors analyze the organizational practices of hip-hop groups from Porto Alegre in Brazil. While hip hop practices are conceived as instances of cultural production they also testify the ways in which social movements develop processes, organize, deliberate, and build structures. The case thus reinforces arguments about the pertinence of studying social movements in the field of organization studies.

The paper by Gelis Filho applies Lacanian theories of discourse to analyze the relationship between Sustainability, Capitalism and China's Economic Expansion. The analysis reveals that the discourse of sustainability, as it is presented today, is fundamentally flawed, since it focuses on the notion of "sustainable consumption" while neutralizing the much more powerful discourse of "reducing consumption". China's economic success derives, in that sense, from its ability to find a niche as the provider of consumption possibilities for Westerners.

The paper by Perlo et al. seeks to understand the complex processes of collective learning prior to explore and design tools that enable the development of this concept. The authors highlight fragmentation in the organizational network, which enclose themselves in a sterile vacuum that prevents the flow of the creative tension that processes of transformation and change require. At the end, the paper proposes an integrative synthesis to open new horizons and bridge organizational gaps.

The paper by Borges and Gonçalo aims to understand the interaction between sensemaking and trust in the construction and response to unexpected events. The theoretical framework integrates Weick's work on sensemaking in high reliability organizations with Luhmann's conceptualization of trust. This framework is applied to the empirical investigation of a recent disruption at the operations center of the Brazilian electrical system.

The paper by Guarido Filho and Machado-da-Silva (in memoriam) maps the construction of the institutional perspective within the field organizational studies in Brazil from 1993 to 2007. The authors consider transformations in the substantive content of academic articles as well as the social organization of scientists. The findings reveal that social ties among scientists in the field of institutional theory are representative of intellectual affinity, which means that there are social mechanisms participating in the process of diffusion of ideas and formation of shared understandings.

The paper by Donnelly draws on actor-network theory and the sociology of translation to enhance our understanding of institutionalization processes and practices. Using Ireland's Industrial Development Authority as empirical example, the author seeks to address "the role of agency, power, persistence and change in the process of institutionalization".

The paper by Lopez Jimenez discusses the use of contracts as the prevailing coordination mechanism in information systems (IS) innovation processes. Drawing on institutional theory, this paper argues that IS innovations take place in a relatively weak institutional context, which accounts for the generalised preference for contracts over other coordination mechanisms (i.e. trust) as a means of governing interorganizational exchange. Two constituent elements of the institutional context of IS 
innovations are analysed, namely the institutional aspects of the information technology (IT) industry and the legal system.

The paper by Kirjavainen et al. considers the new managerial and leadership challenges arising from the shift to knowledge intensive forms of work. Evidence is provided by a study conducted in an international Finnish-lead company and focusing on product development practices. The results highlight the paradoxical role of power and control, and reveal that employees need freedom and yet strong guidance and managerial commitment to develop work in order to stay motivated.

The paper by Giraldo Oliveros et al. explores issues of power from an Activity Theory perspective. The empirical focus is on service encounters between providers and customers in the Higher Education market in Colombia. The authors view service encounters as a social space with inner contradictions that lead to cracks and conflicts for power and control. These contradictions and power play affect collaboration and value actualization in interactions, thus hindering institutional development of Higher Education.

Finally, the invited paper by Mandiola et al. discusses the role of business schools in Chile in relation to the wider institutional and structural contexts within which they function. It is argued that management education has shifted to a market-based logic as a result of alignment with the wider political and socio-economic changes associated with the development of market economies and economic globalization. The authors take a critical standpoint to analyze the consequences of the Chilean neoliberal revolution during the final years of the last century.

The above papers represent an important contribution to both established and emerging themes in Organization Studies, including the relation between civic society, cooperation and development; the organizational implications of social movements; the interplay between knowledge, learning and innovation; and the dynamics of power in organizations and institutions. While echoes of LAEMOS in Buenos Aires are slowly fading away, this collection of papers constitutes a valuable trace of a promising wave in organizational research, one that will hopefully play a role in strengthening the link between Latin America and Europe.

\section{Gerardo Patriotta}

\section{Guest Editor}

We are writing with the sad news that Professor Clóvis L. Machado-da-Silva died on the $26^{\text {th }}$ June 2010 . We would like to acknowledge him as a long-standing and wellrespected member of the academic community in Brazil. His work is among the contributors of this issue as he was an enthusiastic sponsor of the LAEMOS meetings.

\section{Ana Lucia Guedes}

\section{Editor}

